\title{
Drying of stanley plum with some post-harvest applications
}

\author{
Firat Ege KARAAT ${ }^{\text {ID } 1}$ \\ ${ }^{1}$ Adiyaman University, Faculty of Agricultural Science and Technologies, Adıyaman \\ Alınış tarihi: 20 Mart 2019, Kabul tarihi: 19 Temmuz 2019 \\ Sorumlu yazar: Firat Ege KARAAT, e-posta: fkaraat@adiyaman.edu.tr
}

\begin{abstract}
This study was conducted to observe the effects of some physical, chemical and microwave pretreatments on drying period and prune colour of Stanley plums dried in the sun. For this aim, seven pretreatments including piercing with thin needle, cutting fruit layer by knife, microwave application, dipping into solutions of $\mathrm{NaOH}$ and $\mathrm{K}_{2} \mathrm{CO}_{3}$ with or without olive oil addition were compared with untreated samples. Microwave application was the most effective pretreatment in reducing drying time $(95 \mathrm{~h})$ while control was the slowest drying application (401 h). Microwave and other chemical applications negatively affected colour by increasing redness of prunes. Olive oil addition decreased this negative effect but decelerated drying process. Layer cutting were concluded to be a promising method since it significantly accelerated drying while saving colour of prunes.
\end{abstract}

Key words: Drying curve, plum, pretreatment, prune, quality

\section{Bazı hasat sonrası uygulamaları ile stanley eriğinin kurutulması}

Öz

Bu çalışma bazı fiziksel, kimyasal ve mikrodalga ön uygulamalarının güneş altında kurutulan Stanley çeşidine ait erik örneklerinde kuruma süresi ve kuru erik rengi üzerine etkisinin belirlenmesi amacıyla yürütülmüştür. $\mathrm{Bu}$ amaçla ince iğne ile meyvelerin delinmesi, bıçak ile meyve kabuğunun çizilmesi, mikrodalga uygulaması, $\mathrm{NaOH}$ ve $\mathrm{K}_{2} \mathrm{CO}_{3}$ solüsyonlarına zeytinyağı ilaveli veya ilavesiz olarak daldırma uygulamaları ile uygulama yapılmamış örnekler karşılaştırılmıştır. Mikrodalga uygulaması kurutma süresinin kisaltılmasında en etkili uygulama olmuş (95 s), kontrol en yavaş kuruyan uygulama (401 s) olmuştur. Mikrodalga uygulaması ve diğer kimyasal uygulamalarının kuru erik kalitesine kızıl renk oluşumunu artırarak olumsuz etkisi olmuştur. Zeytinyağı ilavesi bu olumsuz etkileri azaltmış, fakat kurutma süresi uzatmıştır. Meyve kabuğunun çizilmesi uygulamasının meyve rengini koruyarak önemli seviyede kurutma süresini kısaltmasıyla ümitvar bir uygulama olduğu sonucuna varılmıştır.

Anahtar kelimeler: Kurutma eğrisi, erik, ön işlem, kuru erik, kalite

\section{Introduction}

Being natural sources of raw fiber, nutrients, vitamins and minerals, fruits are essential for our diet. However, their seasonal production and perishable structure, limit availability of fruits. This fact has led the need for different technologies to preserve fruits and make them available for longer periods. For this aim, drying has been counted as one of the most effective way and applied for agricultural products for many centuries in traditional methods but also in modern methods, drying machine, solar drying, etc., have been applied in last decades (Turan, 2018; Zhang et al., 2016).

Plum is a so commonly dried fruit that dried forms of plums are called a special name, Prune. Together with extending shelf-life, drying of plums eases transportation, packing and shipping. Furthermore, plums achieve a characteristic flavour when they are dried and so reach a different demand from fresh fruit. Today, in addition to its direct consumption as 
snacks, prune is consumed in different ways such as for its juice, syrup and flavoring in the food industry (Sabarez et al., 2000). Hence, more than 200.000 tons of dried plums are produced worldwide annually (INC, 2019).

Even though plums are dried by different methods, open sun drying is still widely practiced because of it is a cost-effective and natural method (Dincer, 1996; Doymaz, 2004; Karathanos and Belessiotis, 1997; Pala et al., 1996). On the other hand, the exposure to environmental contamination, cloudiness, quantitative loses due to such factors as rodents, birds, insects, dust and manual labor requirement are some of its disadvantages (Abdelhaq and Labuza, 1987; Kostaropoulos and Saravacos, 1997). Because of those disadvantages, reducing drying time has crucial importance in open sun plum drying. Since plums are covered within a waxy thin layer, pretreatment of plums to decrease the effect of waxy layer has been accepted as the most effective way to reduce drying time of plums. For this purpose, extensive studies have been conducted and various physical and chemical pretreatments have been proposed. In a study, superficial abrasion of the plums peel compared with dipping into solution of ethyl oleate and physical pretreatment was found to be more effective (Cinquanta et al., 2002). Tarhan (2007) compared six chemical and dipping into hot water pretreatment combinations for drying of plums and reported that the best pretreatment was dipping in $1 \% \mathrm{NaOH}$ solution. Jazini and Hatamipour (2010) compared dipping of plums in hot $1 \% \mathrm{NaOH}$ solution and piercing with thin needle. They concluded that pretreatment of plums consists of piercing of plums by a thin needle could reduce the drying time more than pretreatment by $\mathrm{NaOH}$ solution.

In summary, optimal method of pretreatment reduces drying period while saving quality of the product (attractiveness, color, taste, nutrient content etc.). In this study, a combination of physical, chemical and microwave pretreatments in order to select the best method to be used as pretreatment for plum drying. For this aim, dipping in $1 \% \mathrm{NaOH}$ solution, piercing with thin needle which were reported as effective methods in previous studies. In addition to those applications, layer cutting, a local technique commonly practiced in study area, microwave application and dipping into $\mathrm{K}_{2} \mathrm{CO}_{3}$ solution and $\mathrm{K}_{2} \mathrm{CO}_{3}$ solution mixed with olive oil were tried as new pretreatment methods for plum drying (Dev et al., 2008; Çağlar et al., 2009; Tarhan, 2007).

\section{Materials and Methods}

Experimental area is located in Inonu University Battalgazi Campus in Malatya Province of Turkey (NL35.54'39.03', EL38.45'39.08', 720 m) Plum samples of Stanley cultivar were hand-picked at commercial maturity (Güneyli and Onursal, 2014). The samples were collected from research orchards in the experimental area and dried under open atmosphere until they reach the moisture loss of $75 \%$. Picking, pretreatment and initiation of sun drying process were done on 15.08.2016. During the whole drying period, mean maximum and minimum temperatures were $37^{\circ} \mathrm{C}$ and $17^{\circ} \mathrm{C}$, and mean maximum and minimum relative humidity were $51 \%$ and $14 \%$ at the research area, respectively. (MGM, 2019)

The study was conducted with three replicates for each pretreatment method. Statistical analyses were performed by SPSS for Windows Software according to Duncan's test under the significance level of 0.01 . Totally seven pretreatments were applied and control samples were not treated before drying (Table 1).

\section{Physical pretreatments}

Piercing of fruits with thin needle $(0.7 \mathrm{~mm}$ diameter $)$ was one of the physical pretreatments. According to this method, 20 holes were created on each fruit. Another treatment was cutting layer by knife. In this method layer of fruit samples were cut by knife in a way of four fruit long scratches to be attained on the fruits (Jazini and Hatamipour 2010).

\section{Chemical pretreatments}

Four chemical pretreatments were applied as dipping in solutions prepared by different chemical ingredients. T5 samples were dipped into $60^{\circ} \mathrm{C} 1 \%$ $\mathrm{NaOH}$ solution for 1 minute, T6 samples were dipped into $20^{\circ} \mathrm{C} 5 \% \mathrm{~K}_{2} \mathrm{CO}_{3}+\% 1$ olive oil solution for 5 minutes, $\mathrm{T} 7$ samples were dipped into $60^{\circ} \mathrm{C} 5 \%$ $\mathrm{K}_{2} \mathrm{CO}_{3}+1 \%$ olive oil solution for 1 minute and T8 samples were dipped into $60^{\circ} \mathrm{C} 5 \% \mathrm{~K}_{2} \mathrm{CO}_{3}$ solution for 1 minute (Table 1) (Cinquanta ve ark. 2002; Tarhan, 2007). 


\section{Microwave pretreatment}

According to this pretreatment method, fruits were exposed to microwave application in a microwave pretreatment chamber under $2.5 \mathrm{~W} / \mathrm{g}$ power density for 5 minutes (Dev et al., 2008). These samples were labeled as T4 (Table 1).

Table 1. Pretreatment combinations selected for plum drying

\begin{tabular}{cc}
\hline Treatment & Treatment Combination \\
\hline T1 & No treatment (Control) \\
T2 & Piercing by thin needle \\
T3 & Layer cutting by knife \\
T4 & Microwave $(2.5 \mathrm{~g} / \mathrm{w}, 5$ minutes $)$ \\
T5 & NaOH $1 \%\left(60^{\circ} \mathrm{C}, 1\right.$ minute $)$ \\
T6 & $\mathrm{K}_{2} \mathrm{CO}_{3} 5 \%+$ Olive oil $1 \%\left(20^{\circ} \mathrm{C}, 5\right.$ minutes $)$ \\
T7 & $\mathrm{K}_{2} \mathrm{CO}_{3} 5 \%+$ Olive oil $1 \%\left(60^{\circ} \mathrm{C}, 1\right.$ minute $)$ \\
T8 & $\mathrm{K}_{2} \mathrm{CO}_{3} 5 \%\left(60^{\circ} \mathrm{C}, 1\right.$ minute $)$ \\
\hline
\end{tabular}

Plum samples were weighed each 24 hour from the beginning until the end of drying with $0.01 \mathrm{~g}$ sensitivity digital precision scale (Ohaus, PAJ812). Weight loss percentages (WLP) of samples during drying processes were calculated according to below formula. Wi indicates the weight of plum samples at the beginning of drying process, while $W s$ indicates the weight of plum samples at each weighing point at drying process (Tarhan, 2007). Drying process was finished when WLP is between 74 and 75\% (1).

$W L P=\frac{W i-W s}{W i} \times 100$

Skin colors of dried plums were measured by Color Meter (Konica Minolta, CR-400) according to CIE $1976\left(L^{*}, \mathrm{a}^{*}, \mathrm{~b}^{*}\right)$. The lightness coefficient, " $\mathrm{L}$ " ranges from black $\left(L^{*}=0\right)$ to white $\left(L^{*}=100\right)$. "a" is the color of redness that positive $a^{*}$ indicates a hue of red-purple and negative $a^{*}$ indicates bluish-green. " $b$ " value is yellowness and positive $b^{*}$ indicates yellow while negative $b^{*}$, of blue. The grid origin, $a^{*}$ $=0$ and $b^{*}=0$ indicates achromatic (gray) (McGuire, 1992).

\section{Results and Discussion}

Results of current study were evaluated according to required time for desired moisture content that indicated the main success of the pretreatment and prune skin color which is important for attractiveness of the product. Drying curves and fruit quality levels of each pretreatment group occurred significantly different but still edible fruits were obtained from all sample groups.

Alteration of weight loss percentage (WLP) of plum samples during drying process were illustrated in Figure 1 and drying periods of pretreatment groups were given with statistical classification in Table 2 . Control (T1) was the slowest drying sample and dried in 401 hours and it was followed by pierced samples (T2) with 355 hours. Microwave applied plums (T4) were dried fastest (95 hours) and they were followed by the samples dipped into $60^{\circ} \mathrm{C} 5 \%$ $\mathrm{K}_{2} \mathrm{CO}_{3}$ solution (T8) (151 hours). Plums of $\mathrm{T} 7$ dried in 170 hours while T5, T3 and T6 dried in 182, 200 and 226 hours, respectively.

According to the results, microwave application was found as a beneficial method for reducing drying time together with a drawback similar to the previous studies which were conducted with other fruits and vegetables (Dev et al., 2008; Zhang et al., 2006). Likewise reported by Nijhuis et al. (2008), the possibility of undesirable changes in the food texture, for example being cooked and/or roasted, might be caused by too rapid mass transportation by power of microwave was observed in this study as well. Therefore, this fact must be paid attention in practice and in a more serious circumstance for example when applying to another plum cultivar, a reduced dosage and/or application time can be suggested as two valid solutions to overcome probable problems.

In this current study, piercing with thin needle did not perform as good as reported by Jazini and Hatamipour (2010). The contrast between the results could be caused by difference in the drying methods and plum cultivars used in the studies. Cutting the layer by knife, a common local method but inadequately reported in previous studies for plums, was found as a promising pretreatment especially where a natural and simple method is needed.

Results of this study showed that all pretreatments significantly reduced drying periods when compared with control samples, and chemical pretreatments were more effective than physical ones in reducing drying time. Nevertheless, solution temperature played a key role in this effect. Indeed, the results of T6 and T7 showed that solution temperature caused a significant difference in drying period. As a matter of fact, drying process of $\mathrm{T} 6$ was even slower than layer cutting method. 
The color scales $\left(L^{*}, a^{*}, b^{*}\right)$ were detected on the skin of prunes were shown in Table 2. $L^{*}$ values of pretreated plums were lower than untreated prunes and this difference could be seen on prunes especially on the samples of which their layer cut by knife and dipped into olive oil added solutions. Pretreatment methods of T4 and T8 increased the yellowness values of prunes when compared with untreated samples but those changes were not significantly visible. Prunes treated by microwave (T4), $1 \% \mathrm{NaOH}$ (T5) and $\% 5 \mathrm{~K}_{2} \mathrm{CO}_{3}$ (T8) solutions resulted with higher redness values. The differences of redness values between the pretreatments were considerably visible that prunes having higher redness value were found to be worse attractive.

Table 2. Results of drying periods and color measurements of different pretreatments

\begin{tabular}{|c|c|c|c|c|}
\hline Treatment & Hours & $L^{*}$ & $a^{*}$ & $\mathrm{~b}^{*}$ \\
\hline $\mathrm{T} 1$ & $401 \mathrm{f}$ & $21.25 \mathrm{a}$ & $3.39 \mathrm{~b}$ & $3.09 \mathrm{~b}$ \\
\hline $\mathrm{T} 2$ & $355 \mathrm{e}$ & $19.13 \mathrm{ab}$ & $2.32 \mathrm{c}$ & $2.09 \mathrm{~cd}$ \\
\hline T3 & $200 \mathrm{~cd}$ & $17.09 \mathrm{cb}$ & $2.66 \mathrm{cb}$ & $1.73 \mathrm{~d}$ \\
\hline $\mathrm{T} 4$ & $95 \mathrm{a}$ & $18.99 \mathrm{ab}$ & $5.44 \mathrm{ab}$ & $3.47 \mathrm{ab}$ \\
\hline T5 & $182 \mathrm{bcd}$ & $17.87 \mathrm{~b}$ & $4.84 \mathrm{ab}$ & $3.28 \mathrm{~b}$ \\
\hline T6 & $226 \mathrm{~d}$ & $17.57 \mathrm{~b}$ & $1.66 \mathrm{~d}$ & $1.66 \mathrm{~d}$ \\
\hline $\mathrm{T} 7$ & $170 \mathrm{bc}$ & $16.82 \mathrm{c}$ & $3.36 \mathrm{~b}$ & $2.58 \mathrm{c}$ \\
\hline T8 & $151 \mathrm{~b}$ & $19.15 \mathrm{ab}$ & $6.34 \mathrm{a}$ & $4.06 \mathrm{a}$ \\
\hline
\end{tabular}

Differences between values signed with different letters are significant at $\mathrm{P} \leq 0.05$

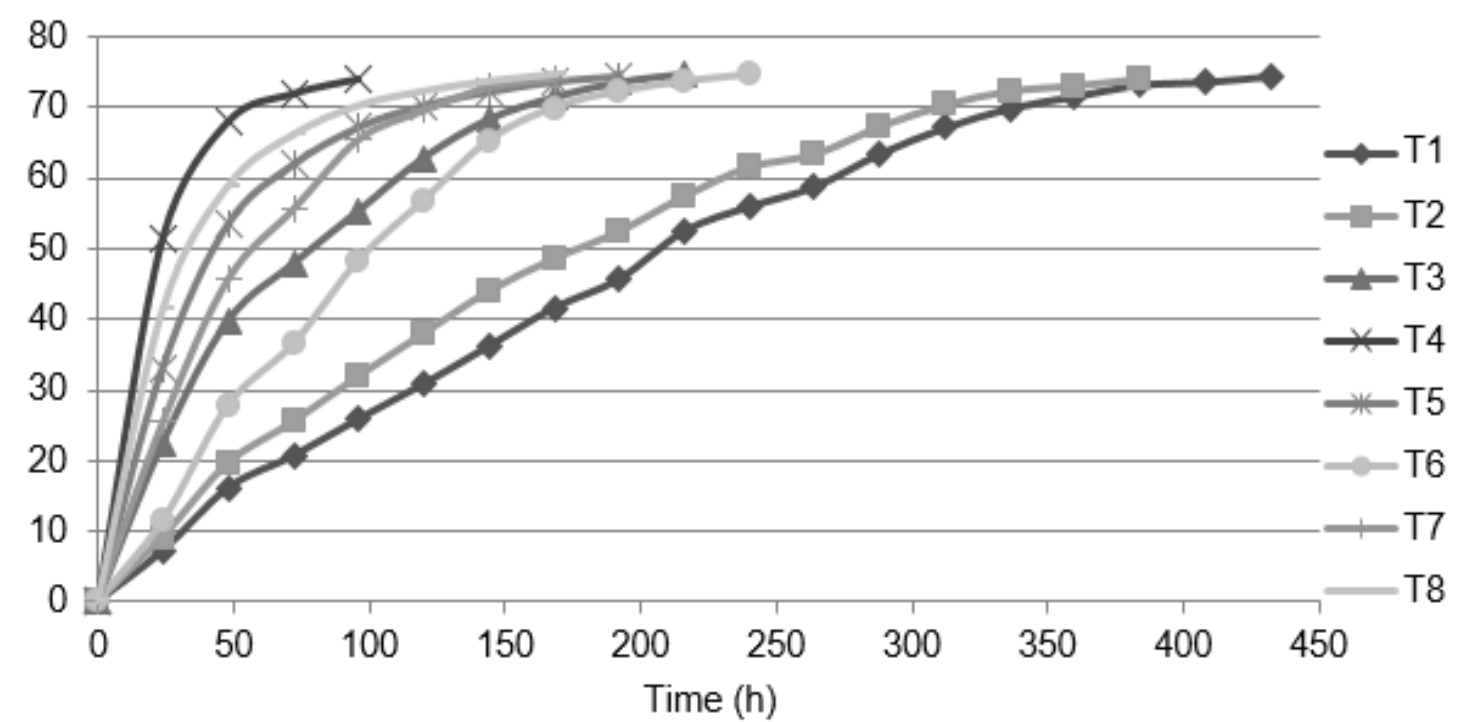

Figure 1. The weight loss percentage values (WLP) of plums over time

The results of this study suggest that $5 \% \mathrm{~K}_{2} \mathrm{CO}_{3}$ solution, with or without olive oil addition, is a better formula than $1 \% \mathrm{NaOH}$ solution which has been reported as one of the best chemical pretreatments in previous studies for plum drying (Jazini and Hatamipour 2010; Tarhan, 2007). However, both $\mathrm{NaOH}$ and $\mathrm{K}_{2} \mathrm{CO}_{3}$ applications cause undesired color alterations and thereby quality loses. Based on the results of $\mathrm{T} 6$ and $\mathrm{T} 7$, it can be inferred that lower solution temperature decreases color alterations caused by chemical pretreatments. Similarly, olive oil addition to pretreatment solution improves quality of prunes by contributing a shiny skin finish and protecting against discoloration caused by chemicals and sun light. However, olive oil addition to pretreatment solution decelerates drying process probably because of moisture lost inhibition from the cracks obtained by abrasion effect of chemicals. 


\section{Conclusions}

Although chemical pretreatments have notable potential for reducing drying time, they are being discouraged since consumers demand natural and safe food especially with organic foods becoming more popular. This fact brings the requirement for healthier and safer methods in food processing. For those reasons, the effects of some physical and chemical pretreatment combinations and microwave pretreatment on the drying qualification of plums at sun drying method were compared in this study. The study was resulted with original findings with a potential useful support in practice for stakeholders. When the pretreatment methods included in this study evaluated together with their strengths and weaknesses, especially physical methods were concluded as beneficial pretreatments to obtain high quality prunes while reducing drying period. Another benefit of physical methods would be the convenience for organic production.

\section{References}

Abdelhaq, E. H., Labuza, T. P., 1987. Air drying characteristics of apricots. Journal of Food Science, 52(2): 342-345.

Cinquanta, L., DiMatteo, M., Esti, M., 2002. Physical pretreatment of plums (Prunus domestica). Part 2. Effect of the quality characteristics of different prune cultivars. Food Chemistry, 79: 233-238.

Çağlar, A., Toğrul, İ. T., Toğrul, H., 2009. Moisture and thermal diffusivity of seedless grape under infrared drying. Food and Bioproducts Processing, 87(4): 292-300

Dev, S. R. S., Padmini, T., Adedeji, A., Gariépy, Y., Raghavan, G. S. V., 2008. A comparative study on the effect of chemical, microwave, and pulsed electric pretreatments on convective drying and quality of raisins. Drying Technology, 26(10): 1238-1243.

Dincer, I., 1996. Sun drying of sultana grapes. Drying Technology, 14 (7-8): 1827-1838.

Doymaz, İ., 2004. Effect of dipping treatment on air drying of plums. Journal of Food Engineering, 64(4): 465470.

Güneyli, A., Onursal, C.E., 2014. Ilıman iklim meyve türlerinde hasat kriterleri (Harvest criteria in temperate fruits). - Gıda, Tarım ve Hayvancılık Bakanlığı, Meyvecilik Araștırma Enstitüsü (Minisry of Food, Agriculture and Livestock, Fruit Research Institute)

http://arastirma.tarim.gov.tr/marem/Belgeler/Yet i\%C5\%9Ftiricilik\%20Bilgileri/Il\%C4\%B1man\%20 \%C4\%B0klim\%20Meyvelerinde\%20Hasat\%20Krit erleri.pdf (Available Date: 17.05.2019).

INC, 2019. Nuts and Dried Fruits Statistical Yearbook 2017-2018, International Nut\&Dried Fruit Council.

Jazini, M. H., Hatamipour, M. S., 2010. A new physical pretreatment of plum for drying. Food and Bioproducts Processing, 88(2): 133-137.

Karathanos, V. T., Belessiotis, V. G., 1997. Sun and artificial air drying kinetics of some agricultural products. Journal of Food Engineering, 31(1): 35-46.

Kostaropoulos, A. E., Saravacos, G. D., 1995. Microwave pretreatment for sun-dried raisins. Journal of Food Science, 60(2): 344-347.

McGuire, R. G., 1992. Reporting of objective color measurements. HortScience, 27(12): 1254-1255.

MGM, 2019. Resmi İstatistikler, T.C. Tarım ve Orman Bakanlığı, Meteoroloji Genel Müdürlüğü (Cities \& Holiday Resorts, Turkish State Meteorological Service).

Nijhuis, H. H., Torringa, H. M., Muresan, S., Yuksel, D., Leguijt, C., Kloek, W., 1998. Approaches to improving the quality of dried fruit and vegetables. Trends in Food Science \& Technology, 9(1): 13-20.

Pala, M., Mahmutoglu, T., Saygi, B., 1996. Effects of pretreatments on the quality of open-air and solar dried apricots. Nahrung, 40(3), 137-141.

Sabarez, H. T., Price, W.E., Korth, J., 2000. Volatile changes during dehydration of d'Agen prunes. Journal of Agricultural and Food Chemistry, 48(5), 18381842.

Tarhan, S., 2007. Selection of chemical and thermal pretreatment combination for plum drying at low and moderate drying air temperatures. Journal of Food Engineering, 79(1): 255-260.

Turan, A., 2018. Effect of drying methods on nut quality of hazelnuts (Corylus avellana L.). Journal of Food Science and Technology, 55(11): 4554-4565. 
Zhang, B., Zheng, A., Zhou, L., Huang, Z., Wang, S., 2016. Developing hot air-assisted radio frequency drying protocols for in-shell walnuts. Emirates Journal of Food and Agriculture, 28(7): 459.
Zhang, M., Tang, J., Mujumdar, A. S., Wang, S., 2006. Trends in microwave-related drying of fruits and vegetables. Trends in Food Science \& Technology, 17(10): 524-534. 